MYTHS OF TENURE SECURITY AND TITLING: ENDOGENOUS, INSTITUTIONAL CHANGE IN CHINA'S DEVELOPMENT

Prof. Dr. Peter Ho

Minzu University of China

Zhongguancun Nandajie 27, Haidian, Beijing, 100081, PR China

Delft University of Technology

PO Box 5015, 2600 GA, Delft, The Netherlands

This research has been supported by the China National Science Foundation, project number 71473286 and the European Research Council, RECOLAND project 282690. 


\title{
MYTHS OF TENURE SECURITY AND TITLING: ENDOGENOUS, INSTITUTIONAL CHANGE OF CHINA'S LAND AND HOUSING
}

\begin{abstract}
Titling is often seen as a precondition for economic growth and the rule of law. By contrast, Chinese real estate has gone through a substantive economic growth without a cadaster, i.e. in the absence of registered rights to realty. Through a detailed review of state interventions since the early $20^{\text {th }}$ century until today two critical points will be substantiated. First, it will be established that the Chinese state's titling schemes never came to fruition. Instead, we will see that titling, as a form of institutional intervention, is by definition a long term, protracted process of negotiation and dispute between state and other actors. In fact, the contemporary origins of Chinese titling can be traced to almost a century ago, the early 1920s. Second, it will be demonstrated that Chinese titling revolves around three "battlegrounds of bargaining" - major sources of conflict that require resolution over time: i) the status of state and collective ownership; ii) the fragmented authority over land; and iii) the separation of land from housing. In this context, it is maintained that the cadaster, as a significant socio-economic and spatial institution, is the resultant of development rather than its sine qua non.
\end{abstract}

Keywords:

Land and housing policy, land registration and administration, real estate, urban and rural planning

\section{Introduction: Development without titling}

Land development and real estate constitute a major portion of the economic growth and wealth generated in China. Well before the surge in real estate development, total 
average revenues from the sale of land use rights ${ }^{1}$ had already aggregated to over a quarter of local government budgets during 1995-2002 (Lin, 2009, pp.274-5). ${ }^{2}$ A recent report estimated that revenues from land sales could account for an even greater amount of approximately 40 percent of local government budgets (Chavonec 2012b). ${ }^{3}$ Similarly, real estate has also rapidly increased in significance (Stein, 2012, p.4). According to the National Bureau of Statistics, real estate investment grew at a rate of 27.9 percent in 2011 compared to the previous year. ${ }^{4}$

At the same time, China has not completed land titling. Even more, it is not expected that titling can be accomplished in the near future. It might be difficult to comprehend how Chinese development could have occurred without secure, transparent, and formal property rights. In a Western industrialized context, it would be unimaginable, for instance, to purchase a home without concrete evidence of ownership. ${ }^{5}$ This led an observer to note more than ten years ago: "Making title to its new transferable land use rights secure is of paramount importance if China is to attract foreign investors and sustain its new market economy" (Palomar 2002, 1). ${ }^{6}$ Enigmatically, the country's double-digit growth and upsurge in land development have occurred precisely over the previous decades (Yueh, 2013; Lin, 2009; Hsing, 2010; Stein, 2012). Therefore, the tantalizing paradox of Chinese development - economic growth in the absence of secure, private and formal property rights - is perhaps nowhere more

\footnotetext{
${ }^{1}$ In particular, the revenue through "land conveyance" or churangjin, i.e. the sale of land use rights by the state to real estate developers on the so-called primary land market. The real estate market was liberalized in 1998 with the initiation of national housing reform.

${ }^{2}$ More specifically, this was calculated by Lin to be 26.2 percent of the budget of local government.

${ }^{3}$ However, in this regard, it is important to recognize that the proportion of land revenues is difficult to calculate as it is often understated or even concealed from regular budgetary overviews. For instance, it is probable that it is neither included in local government's intra-budgetary (yusuan nei) nor in the extra-budgetary (yusuan wai) income stream but is most likely included in the ill-defined extra-institutional (zhidu wai) revenues. Moreover, for a more accurate picture, it is crucial not to focus on gross income but, instead, on net income, i.e. the costs for expropriation and development should be excluded. Oral communication, 31 January 2013, professor George Lin, Hong Kong University.

${ }^{4}$ Chovanec, however, has calculated that this figure is incorrect because it is a nominal rate whereas the GDP growth rate figures are real figures (adjusted for inflation). The real (and, therefore, comparable) rate of expansion for real estate investment in 2011 should, according to him, be $20.0 \%$ (Chovanec 2012a, 1).

${ }^{5}$ However, in this regard, Clarke rightly pointed out that much of "the debate over [Chinese] state ownership is a distraction - the label turns out to have little if any determinate meaning, and virtually any social purpose can be accomplished with or without the form of state land ownership" (2014: 323).

${ }^{6}$ Over the years, this argument has not significantly changed, as shown in a writing by Yale professor Ellickson (2012: 3).
} 
visible than with land as a means of production (see also Clarke, 2014).

This article aims to contribute to the discussion by charting the Chinese state's efforts in land titling. The paper is based on primary, historical Chinese sources hitherto unavailable in English, such as internal Party and government notices, interpretations of laws and regulations, minutes, and rulings by the Supreme People's Court. Where these are absent, secondary sources were used such as memoires, biographies, and historiographies. The research was complemented by a series of 43 in-depth interviews conducted with senior government officials, legal experts, and academics. The analyzed period covers over a century (1911-2015), from the establishment of the Chinese Republic until the present. This article begins with an explanation of the theoretical relevance of the focus on the cadaster and titling in order to better comprehend institutional change. The subsequent section reviews the central state's titling efforts of urban and rural land and housing since the beginning of the Republican Period. The final section discusses the three parameters that affect the institutional dynamics and bargaining over titling.

\section{Theoretical relevance of the cadaster}

\subsection{Conceptualizing institutions}

Different from, for instance, Western Europe and North America, the Chinese state continues to encounter fundamental choices of institutional design. One of the most obvious examples is the cadaster. Here, the term institution is defined as a "set $t^{7}$ of endogenously shaped, context-determined social rules", i.e. defined along three axioms: i) institutions are the result from interaction and, therefore, both cause and effect; ii) political and economic actors cannot intentionally design institutions (albeit

\footnotetext{
${ }^{7}$ It is significant to recognize that an institution is defined in this aspect as a "set of rules" and not a single rule that governs social actors' behavior. For example, a customary rule that commuters in the Beijing subway system should stand on the right side of the escalator and walk on the left side if they are in a hurry is, therefore, not perceived as an institution. Contrarily, the various informal and formal rules that guide the behavior of Chinese subway commuters - ranging from how to board trains to giving up your seat for the elderly, an invalid, and women with children - could be perceived as an institution.
} 
having intentions), as institutions are the outcome of an autonomously emerging order, and lastly; iii) institutions are time and space-specific and as such, determined by the use and disuse of their function, reflected through actors' aggregate perceptions of institutional credibility (Ho, 2013, pp.1089-90; Grabel, 2000; Chang, 2007).

Defined along these axioms, the cadaster is, therefore, one of a multitude of possible institutions. In other words, a formal law or right of ownership is an institution inasmuch as informal, customary law regarding forest, wasteland or grassland may be deemed an institution. Thus, the word "cadaster" in this aspect refers to its (Western) conceptualization of how institutions should appear based on certain axioms or political considerations. The term is thus employed as an ideal-type, theoretical notion in contrast to the variety of institutions one could possibly encounter in time and space. $^{8}$

Fundamentally, the land registry or cadaster (derived from the French cadastre) ${ }^{9}$ is a system whereby ownership of land plots is registered (generally by the state) to provide proof of title. The cadaster is entwined with concepts regarding the legal protection of ownership ${ }^{10}$ as the absolute, supreme right among legal rights, ${ }^{11}$ and is perceived to be situated at the nexus of control over land and real estate. Yet, in

\footnotetext{
${ }^{8}$ For instance, various classical legal-anthropological studies have demonstrated how Western norms and values define the concept of ownership and how ownership may be conceptualized quite differently in other cultures and societies (Van Vollenhoven, 1909; Sonius, 1963; Von Benda-Beckman, 1979). Also, in the case of imperial China, for which reliable, empirical material is difficult to obtain, studies have discovered differences in the conceptualization of property. Zelin (1986: 20, 31-32), for example, has indicated that the contemporary notion of "private property" did not exist in rural, imperial China as it was considered a form of common property jointly owned and exploited by a farm household. See also (Pomeranz, 2005).

${ }_{9}$ The French term is, in turn, attributed to the Late Latin capitastrum, a register of the poll tax and the Greek katastikhon, a list or register literally from kata stikhon, "down the line", in the sense of "line by line."

${ }^{10}$ Ownership is legally considered to comprise all other rights. As Van den Bergh (1996: 172) wrote: "Ownership is the supreme right; there can be no rights which would not be contained in ownership." In this regard, Demsetz' (1967) definition of property as a "bundle of rights" is relevant as well as Honoré's (1961: 113) definition of ownership as: “... the right to possess, the right to use, the right to manage, the right to the income of the thing, the right to the capital, the right to security, the rights or incidents of transmissibility and absence of term, the prohibition of harmful use, liability to execution, and the incident of residuarity: this makes eleven leading incidents."

${ }^{11}$ As Van den Bergh critically characterized the civil law concept of ownership: "Ownership is absolute: apart from what the law expressly forbids, the owner may do whatever he likes, he can exclude everybody else from influencing the goods, everybody else is obliged to abstain from breaching his ownership rights, the owner is the supreme ruler over his goods" (1996: 172). However, Sonius has noted that "absolute ownership does not exist and has never existed. Ownership has always (in Justinian law as well) been restricted by all types of regulations which, in the general interest or in the interest of others, deprived the owner of part of his absolute power over the object" (1963: 19).
} 
globalized, urbanized society, the cadaster is more than a vehicle on which to record rights. ${ }^{12}$ In fact, in highly industrialized economies, the cadaster functions as an overarching institutional repository for data related to space, environment, land, housing, infrastructure and taxation. It should come as no surprise that - rightly or wrongly so - the cadaster is often portrayed as an institutional epitome of Western capitalist development (De Soto, 2000, p.47). ${ }^{13}$

\subsection{Title versus Deed: The Act of Registration}

Whereas the cadaster is the register that records and establishes title, the act leading to its establishment is referred to as titling. The term is often intermingled with "land registration." For all clarity, whereas title is the legal proof that establishes an entity (e.g. person or business) as the owner of a property, registration is the requirement by the state to demonstrate one has registered, and paid any taxes or fees due. Titling constitutes answering the following questions: whose property; how much; and where? Thus, it is the process by which rights such as ownership, use, and management are recorded per parcel ${ }^{14}$ to satisfy evidence of title, facilitate transactions, and prevent unlawful disposal. Yet, titling is more than surveying, measuring, and assessing various rights and claims to land. Particularly in a developing context of institutional change, titling is perceived as an act of social engineering. Titling is then tantamount to the establishment of new social rules by the state (or a foreign donor, developing agency, or consultancy firm, for that matter) to modify local norms, values and

\footnotetext{
${ }^{12}$ As Rowton-Simpson $(1976,3)$ correctly noted: "study of land registration must clearly distinguish between its public and private function." The former function typically relates to taxation, spatial planning and environmental management whereas the latter ensures "the rights of the owner or occupier of the land and to enable him to conduct his land transactions safely, cheaply and quickly."

${ }^{13}$ The same reasoning, for instance, contributes to North and Thomas' The Rise of the Western World in which they noted: "In general, we shall observe that governments were able to define and enforce property rights at a lower cost than could voluntary groups and that these gains became even more pronounced as markets expanded. Therefore, voluntary groups had an incentive to trade revenue taxes in return for the rigorous definition and enforcement of property rights by government" (1973, p. 7).

${ }^{14}$ These rights may also include many other rights including usufruct, right of way, or any right considered to be a component of a "bundle of rights." See Demsetz (1967). In relationship to the registration per parcel, Dale and McLaughlin $(1988,12)$ wrote: "In a parcel-based land information system, or cadaster, the data are organized around the cadastral parcel. This is generally the proprietary land unit, but it can be any tract of land that is part of an estate and has a separable identity."
} 
customs (e.g. Dale and McLaughlin, 1988, p.21). However, as this article demonstrates: reality is more unruly.

Land titling is typically classified under common or civil law systems. The contemporary origins of the civil law version of land titling date back to the early $19^{\text {th }}$ Century when the Napoleonic Code (or Code Civil des Français) was established under Napoléon I in 1804. In accordance with the common law prior to the mid-19 Century, land owners were required to verify ownership of a parcel retroactive to the earliest grant of land by the Crown. The documents related to this chain of transactions were known as "deeds". Bearing in mind that the Domesday Book ${ }^{15}$ was completed in 1086, there is significant probability that many property exchanges could have occurred since that time. As a consequence, ownership could be easily challenged, causing substantive legal costs. To solve these discrepancies, the premier of South Australia, Sir Robert Richard Torrens, introduced the title registration system in 1857. The "Torrens title", named after him, is a system where a state register of land holdings guarantees an indefeasible title to those included in the registrar. Land ownership is transferred through the utilization of title registration instead of deeds which facilitated transactions and certified ownership of an absolute title to realty. The Torrens system has become pervasive around the Commonwealth of Nations and is closely related to the Napoleonic cadaster (Rowton-Simpson 1976, Dale and McLaughlin, 1988).

However, as Dowson and Sheppard (1956, p. 98) aptly noted: "No genuine classification of the variant statutes according to differences in system is possible" and "even the distinction between Torrens and English origins becomes blurred as problems are re-examined and dealt with on their own in the light of modern developments." In summary, development may yield limitless institutional variations that can be perceived as credible according to social actors, and the Chinese cadaster as an institution is no exception.

\footnotetext{
15 The Domesday Book is the oldest land survey of much of England and parts of Wales executed under the auspices of William I of England.
} 


\section{China's titling over time: Property and Modernization}

The second section of this article delves into China's contemporary efforts in titling. It assesses how the state's efforts at land titling failed to materialize since the fall of the Qing dynasty in 1911. As illustrated above, the cadaster is a crucial institution in the transaction and administration of land as a means of production which is the reason that it is not easy to escape from the concepts of modernization and economic progress where titling is concerned. As societies evolve from predominantly traditional, agrarian economies into industrialized, highly capital- and technology-intensive economies, distinct stages of institutional development that appear or can be induced under specific socio-economic conditions may be discerned. However, beliefs regarding teleology and "institutional determinism" 16 are not without risk.

Certain scholars claim that the origins of Chinese titling date back 5,000 years ago and indicate titling as a straight historical line of development from that time until the present-day. ${ }^{17}$ In reality, however, the registration efforts by the Chinese state have been heavily constrained, and titling has been a fragmentary, interrupted process as will be demonstrated in the subsequent sections.

\subsection{Republican period (1911-1949)}

The subversion of the Qing Dynasty in 1911 ended over two millennia of imperial rule. The subsequent establishment of the Nationalist republic can be regarded as the emergence of the modern Chinese nation-state. ${ }^{18}$ In 1922, the Nationalist government proclaimed the "Regulations for the Registration of Real Property" and preparations

\footnotetext{
16 In Inglehart's (1997: 206) words: "[T]he plausibility of the interpretation that institutional determinism is the major explanation is severely undermined by the finds" (italics added).

${ }^{17} \mathrm{Hu}(2007,1)$ asserts that, beginning as early as the legendary emperor Yu of the Xia dynasty (2183-2177 BC), land was surveyed and titled by dividing it into three classes and nine grades for purposes of taxation. He then describes how, during the Zhou Dynasty (1066-256 BC), land was measured and registered according to a measurement of length termed "lian", while the first attempt to create a comprehensive registration of households and land was allegedly done under Qin Shi Huangdi, the first emperor who reunified China in $221 \mathrm{BC}$.

18 Therefore, this point in time will be the beginning point of the institutional analysis of land titling.
} 
were made for titling that would encompass six items, i.e. land property, distribution, management, use, tax and other levies and an undefined "special cases for investigation" (Hu 2007). However, the Nationalist government, while subjected to President Chiang Kai-shek, never realized complete territorial control over China even after the military "Northern Expedition" in $1928 .{ }^{19}$ Therefore, titling did not achieve full fruition.

Armed conflicts that ravaged the country during the republican era had a substantive impact on land ownership. Changes in land ownership had occurred throughout the imperial era when land was frequently abandoned during periods of war and social instability or when natural disasters occurred, and reoccupied by new owners. ${ }^{20}$ These shifts in ownership considerably complicated titling. For example, in Longyan County (Fujian Province), one of the largest land reform projects under republican rule, which encapsulated approximately 18,000 hectares, was achieved in 1929. After the Communist army assumed control over the area, land was confiscated from landlords, rich peasants, ${ }^{21}$ and temples and reallocated to poor farmers, tenants, landless farm laborers, and local communist soldiers. Yet, six years later, in 1935, when the Nationalists recaptured the area, former landowners reclaimed ownership and "great confusion arose between the old and new owners of the land" (Shen, 1951, p.100). ${ }^{22}$

\footnotetext{
${ }_{19}$ Although nominally ruling over China, Chiang wielded effective control over only four provinces: Jiangxi, Zhejiang, Anhui and Jiangsu.

${ }^{20}$ For instance, writing about the period of the Han to the Tang dynasty, covering several centuries from 206 BC until 618 AD, Stuart $(1954,114)$ concludes that: "the problem of land-ownership is a very complicated one. (...) [T] he period was one of great confusion and disturbance (...) one in which direct factual evidence of any kind is extraordinarily scanty." A study of Qing land ownership ascertained that claims to land were considerably weaker if someone had only occupied the land but was not farming it. However, the payment of taxes could significantly reinforce a claim to land to the extent that it could even convert illegally occupied land into property protected by the government (Osborne 2004: 127, 136). In an historical study of the Chinese western frontier region, it was indicated that, during imperial times "due to war and natural disasters, reclamation occurred in a wave-like pattern, waxing and waning (...). In the early Qing, (...) much of the land brought earlier under cultivation was abandoned. Apart from wars of the Ming-Qing transition, the vicissitudes of nature also contributed to this (Ho, 2000: 354-355).

${ }_{21}$ These two groups represent significant components of the constituency of the Nationalist government at the time.

${ }_{22}$ Such confusion is also apparent in the shifts of ownership over time. At the time when Buck compiled his famous study, he recorded 63.2 percent farm owners, 17.1 percent part owners, and 19.7 percent tenants (Buck 1930, 146). Shortly before land reform, Shen $(1951,96)$ discovered that the percentage of farm owners had dropped by 17 percent.
} 


\subsection{Collectivist period (1949-1978)}

After the Nationalists were defeated in the civil war and fled to Taiwan, Mao Zedong established the Communist state in 1949. The crucial difference with the Nationalist republic was that, during the extended period of civil war, the state wielded de facto control over the country. ${ }^{23}$ This afforded the opportunity for nation-wide titling.

It should be noted that titling in the cities was legally less complicated as urban land was state-owned and, therefore, exempt from titling (further explanation below).

In contrast, events in rural China took a different course. The first and last attempts by the Maoist state to survey and register rural land was during the "Four Fixes" movement in 1962 (si guding) which was specified for the registration of land, labor, animals and agricultural tools. ${ }^{24}$ Launched as a nation-wide mass movement, the Four Fixes movement did not induce the creation of a cadaster, and its registers, generally, existed nowhere else other than as intentions in state documents. It can be questioned why it was so difficult to establish the cadaster as a credible, socially supported institution. Contrarily, it can also be questioned why, under the prevailing conditions, the state would possess the ability to establish a cadaster at all.

One explanation is that China's rural ownership structure was (and still is) as ambiguous as it was potentially explosive. During the Land Reform (1950-1952), landlords and rich peasants were expropriated, and their land assets were given to poor and landless farmers for private ownership; in many cases, this was accompanied by the issue of private title. ${ }^{25}$ A few years later, in 1956, private land ownership was abolished, and agricultural land ${ }^{26}$ was pooled into the Higher Agricultural Production Cooperatives. The cooperatives were soon replaced by the People's Communes expansive, unmanageable collective units (sometimes holding up to 50,000 farm households) during the Great Leap Forward campaign in 1958. Consequently, the

\footnotetext{
${ }^{23}$ For more information on this period of Chinese history, see e.g. (Gray, 1990).

${ }^{24}$ Following the Four Fixes movement, titling was not attempted again until the period of the economic reforms in the 1980s.

${ }^{25}$ For an example of a private title issued during the Land Reform, see the photo in (Ho, 2005: 46).

26 But not forest, grassland and wasteland which mainly remained state-owned.
} 
failure of forced collectivization during the Great Leap induced a minimization of communes in 1962. Simultaneously, the commune's ownership of land, labor, and capital was rescinded and divided into three levels ${ }^{27}$ (commune, brigade and team) by which the team (in fact, the actual, physical village) was granted land ownership. The following information demonstrates how this legacy of ownership shifts, expropriations, and institutional reshuffling continues to currently affect China's titling efforts.

\subsection{Reform era (1978-present)}

The trajectory of China's titling that had unfolded beginning in 1978 underscores its incremental, unintentional and unpredictable nature. The state might have ambitions and intentions, however, in the implementation thereof, these become minimal steps on a long, arduous road. To date, China continues to lack a national cadaster. Thus, despite theoretical foundations to the contrary, the country's capitalist growth over the past three decades or so has occurred without formalized, legally protected property rights. In fact, it appears that the cadaster results from development rather than being an institutional precondition.

3.3.1. Urban registration. Titling in China's cities was fundamentally different from titling in the countryside. After the nationalization of industries and companies in the early 1950s, urban land was deemed state-owned, although, due to sensitivities, not legally stipulated for a long period of time. ${ }^{28}$ Land owned by the state was seen as absolute and, therefore, did not warrant a title; a principle adhered to - and enshrined in regulation - until today. ${ }^{29}$ However, the principle did not signify that urban

\footnotetext{
27 This is also known as the implementation of a policy of "three-level ownership" (sanji suoyou).

${ }^{28}$ These sensitivities relate to property owned by urban industrialists and entrepreneurs. As a result, urban land ownership was not addressed in the 1950 Land Reform Law. One of the few references to urban property found - and not even explicitly - is article 12 of the "1947 Great Outline of the Land Law" (tudifa dagang) in (Sun 1998: 100).

${ }_{29}$ See, for instance, article 2 of the 2007 Land Registration Measures that only states that "land registration refers to the titling of state-owned land use rights, collective land ownership, collective land use rights and land mortgage, easements, and other land rights (...)", (Ministry of Land and
} 
ownership was uncontested. The notion that urban land is tantamount to state ownership and, therefore, excludes private ownership had been disputed up to the early 1980s (Xu, 2003, p.603, 680-2; Peng, 1982, p.445). With the onset of the reforms in 1978, descendents of former capitalist entrepreneurs, industrialists, and wealthy families who had previously owned significant tracts of land in the cities secretly hoped to recover confiscated property.

Strikingly, a faction in the government attempted to revert or, at least, account for the existence of private land ownership, which, of course, blatantly contradicts Leninist-Marxist ideology (State Agency for Urban Construction, 1982, p.1). However, the Constitution was revised and adopted shortly thereafter. The revision smothered a potentially disruptive debate regarding private ownership by unequivocally stipulating that: "urban land is state owned" (NPC 1982, article 1). Due to the constitutional revision, the titling of urban land is straightforward: its ownership does not require registration, whereas the use right of urban land and the ownership of housing are registered, respectively, by the Ministry of Land and Resources and the Ministry of Housing and Urban-Rural Development (see section below "Land versus housing").

3.3.2. Rural registration. Preparations for rural titling in the period of reform began soon after the disbandment of the communes. What ensued was an extended process in which the state attempted to specify new "rules of the game." Over time, these rules increased in authority and scope, varying from mere "views" and "administrative measures" to "regulations" and "national laws" which were supported by decisions from the state's highest authorities: the State Council and the Central Committee of the Communist Party.

In 1984, the State Council began to require a comprehensive survey of the nation's land resources $^{30}$ to facilitate land registration. This survey continued for 12 years and, according to estimates by the former State Land Administration, involved approximately 
200,000 officials, local cadres and surveyors and a total investment of 1.2 billion RMB

(State Council, 1984; Ministry of Land and Resources 2007b). Shortly after the survey began, the first Land Administration Law was adopted in 1986 which provided the legal framework for titling. This piece of legislation was specified in more detailed rules in subsequent years. ${ }^{31}$

The year 2007 was critical due to the passing of the long awaited Property Law. ${ }^{32}$ This law made detailed stipulations regarding registration procedures, rights, duties, and liabilities. At the end of the year, the Ministry of Land and Resources (2007) proclaimed the "Measures on Land Registration." Titling was placed on the most significant political agenda during the $17^{\text {th }}$ Party Congress in October 2008. The CCP Central Committee stated that the "assessment of land rights, the titling and the issue of permits should be done well" (CCP, 2008, p.4). In its annual rural plans for 2010, i.e. the Number One Document, ${ }^{33}$ the central state decreed in unusually powerful wording that titles be issued to "all rural collective economic organizations with ownership rights within three years" ${ }^{34}$ (CCP Central Committee and State Council 2010, p.5).

However, when asked to comment, a senior official of the Ministry of Land and Resources stated "it might be hard to complete land registration within 3 years." 35 By

\footnotetext{
${ }^{31}$ In 1989, the former State Land Administration determined the initial main issues in titling which were described in the notice "Certain Views on Problems for Determining Land Rights." These were improved and codified in "Several Administrative Regulations on the Determination of Land Use and Ownership Rights" issued in 1995. Three years later, the Land Administration Law was revised, though this did not significantly modify the regulatory framework for titling.

32 The drafting of the Property Law took nine years spanning the period from 1993-2007 and was fiercely debated after an open letter to the National People's Congress by Peking law professor Gong Xiantian. The letter, dated 12 August 2005, made allegations that the bill violated the Chinese Constitution and betrayed the Socialist System. With specific reference to the forced evictions of farmers and urban home-owners, Gong's letter hit a raw nerve in society, causing public outcry, which delayed the adoption of the Property Law for 2 years (Tang, 2007).

${ }^{33}$ The Chinese state's most important annual rural planning document is the "Central Number One Document" (or zhongyang yihao wenjian) that dictates the main political ambitions for the coming year.

${ }^{34}$ The document also indicated that there were "Constant bright spots in rural reform. The reform of collective forest tenure has had remarkable results; of 25 million $m u\left(1 / 15^{\text {th }}\right.$ ha) of collective forest land, 15.1 million $m u$ has been registered and leased to individual households which accounts for $60 \%$ of the collective forest land" (CCP Central Committee and State Council, 2010: p. 5). However, in a critical article by He and Zhu (2008), it was pointed out that collective forest tenure reform and titling have led to substantial problems and disputes.

35 Oral communication, Interviewee ZXY-5/4/2011, senior engineer, China Land Surveying and Planning Institute, Ministry of Land and Resources, 5 April 2011.
} 
the end of 2011, the Director-General of Land Titling, Zhu Liuhua, announced that:

"According to current records, 70 to 80 percent of the titling of rural collective land has been completed, and it is expected that there will likely be an even better result by the end of the year" (Zhu 2011).

Interestingly, towards the deadline, the 2013 Number One Document extended the completion date for an additional 5 years, until 2018 (CCP Central Committee and State Council 2013, p.2). Why has the Chinese state, despite continued effort, investment, and strong political support, not succeeded in creating a cadaster after approximately 100 years? The answer to this question lies in critical parameters that affect the bargaining over land titling between state-state and state-society actors. ${ }^{36}$ These actors conjointly constrain the intentions of the Chinese state which ultimately experiences its plans as ineffectual or being materialized into a different form.

\section{The reach of the Chinese state}

The third and final section of this article, examines the three "battlegrounds of bargaining" around which the negotiation process on titling occurs: i) the status of collective and state ownership; ii) the fragmentation of authority over land; iii) the separation of land from housing. In fact, this separation counts for built structures in general, which include residential, commercial, industrial and public buildings. However, for reasons of space, this article only concentrates on housing. Each of the three aforementioned parameters will be dealt with individually in the sections below.

\subsection{Collective versus state ownership}

4.1.1. Collective land. During the "Four Fixes" movement, land ownership by the

\footnotetext{
${ }^{36}$ It should be noted that in this China is no exception to the processes of titling in other developing and emerging economies.
} 
commune was abolished and "fixed" at the level of the then production team, i.e. the existing natural village. This was not determined by law but, instead, by Party Decree in the Sixty Work Articles of the Rural People's Communes (nongcun renmin gongshe liushi gongzuo tiaoli) or, in short form, the "Sixty Articles". Yet, granting land ownership to the production team did not completely ensure that the property was secure. During the Maoist period, the team's land was frequently expropriated without fair compensation "for reasons of economic development." ${ }^{, 37}$ In fact, vesting land ownership in the team was heavily contested, and it took years of discussions in the CCP Central Committee before the decision was made. ${ }^{38}$

After the death of Mao in 1976, China decisively embarked on a path of economic reforms under the auspices of Deng Xiaoping. The communes were dismantled practically overnight between 1984 and 1985. As illustrated in Table 1 below, the commune, brigade and team were replaced by new collective units, respectively termed as the town/township (former commune), administrative village (former production brigade) and the villagers' group or natural village (former production team). However, whether the natural village, as the production team's successor, would obtain ownership of rural collective land was not self-evident. Although decreed by Party regulation, later laws remained ambiguous regarding the term collective and, subsequently, about the level in which land ownership should be vested. For this reason, the natural village, as the lowest collective, has never been able to represent and safeguard its members' interests over land, let alone its ownership.

\section{Table 1: Levels of Chinese administration and changes in ownership}

\footnotetext{
37 See, for instance, the various expropriation cases described in (Supreme Court 1997, 334-40 and 341-7) and the discussion of the team's land ownership in Chapter 2 (Ho 2005).

38 This is also reflected in the revision of the Party Decree that stipulated collective land ownership. In the original 1961 draft of the Sixty Articles, Article 17, it is stated: 'all land . . within the limits of the production brigade is owned by the production brigade'. However, by the time the revised draft of the Sixty Articles was issued by the Central Party Committee on 27 September 1962; the team had been granted land ownership (CCP 1961, 454; CCP 1962,137).
} 


\title{
[Insert Table 1 about here]
}

A jurist in favor of reinstating the natural village as the owner once wrote that "if the villagers' committee [of the administrative village] is mandated by all villagers, it is eligible to be the owner of land" but "in reality, the villagers' committee has become an extension of the political power of the township/town (...) as a result of which the collective ownership of farmers is often difficult to realize and farmers cannot enjoy the rights and interests of the collective" (Xu, 1998, 22). China's Supreme Court made a landmark decision when it stipulated that the 1962 Four Fixes, during which land ownership was granted to the team, should be employed as the foundation for land titling. ${ }^{39}$ The State Land Administration (later known as the Ministry of Land and Resources) proceeded in the same manner with its 1989 regulations on land ownership. ${ }^{40}$

Contrarily, others debated that supporting the natural village as the unit of collective land ownership would seriously impede development. The government of Zhejiang Province - one of China's flourishing, urbanizing regions - wrote in a hotly debated proposal to the National People's Congress:

\begin{abstract}
"Some towns have already abolished the limits of the natural village (villagers' group). (...) If we allow ownership to the villagers' group, town and village planning will be difficult to implement, which will hinder economic growth.” It would be better if "the ownership right to collective land of the villagers' group is not stipulated." 41
\end{abstract}

Another argument championing the abolishment of the ownership of the natural

\footnotetext{
39 See the review of the Supreme People's Court on 'The Use of Policies and Laws for the Land Dispute between the Villagers' Committee and the Villagers' Group' described in (Xiang 1996, 293, 312-15).

${ }^{40}$ See the 'State Land Administration's 1989 Regulations on the Assessment of Land Ownership and Use Rights' which indicate 1962 - the year when the Sixty Articles were proclaimed and on which the basis of the Four Fixes Movement was performed - as the standard (Xiang 1996, 293, 312-15).

41 This was indicated in the "Remarks on the "Land Administration Law (Revised Draft)" by Relevant Units and Personnel of Zhejiang Province' (National People's Congress Legislative Work Committee 1998, 366).
} 
village is that the administrative village had engaged in duties of land administration and acted as the de facto owner of collective land. For instance, research (Quanguo Nongcun Guding Guanchadian, 1998) has indicated that the administrative village acted as the lessee of agricultural land in over 60 percent of sampled cases. Moreover, Mao and Wang (2004, p.45) ascertained that, in land concerns, the leverage and authority of the administrative village far exceeds that of the natural village or villagers' group; similar conclusions were also reached by others (e.g. Zhang, 2013; Xiao, 2007).

It is perhaps, for this reason, that the Ministry of Land and Resources reverted from its earlier stance on the Four Fixes as a basis for title in recent draft regulations, (and subsequently countermining the natural village as owner). Instead, it advocates that "if (...) the rural farmers' collective has already abolished the boundaries of the leased land of the villagers' group, [the land] should be owned by that particular rural farmers' collective" (article 24, Ministry of Land and Resources. 2008).

Whereas the 2004 Revised Constitution maintains the ambiguous formulation that rural land is collectively owned without specifying the nature of the collective, the 2007 Property Law demonstrates even more significant change. For the very first time, national law distinguishes between levels of collective ownership:

1. 'If it is owned by a farmers' collective of a village, the ownership shall be exercised by a collective economic organization or the villagers' committee (read: administrative village, $\mathrm{PH}$ ) of the village on behalf of the collective;

2. If it is owned by two or more farmers' collectives, the ownership shall be exercised by all the collective economic organizations or the villagers' groups (read: natural villages) of the village on behalf of the collective; and

3. If it is owned by a farmers' collective of a town (read: town/township), the ownership shall be exercised by a collective economic organization of the town on behalf of the collective."

However, despite this effort, the Property Law merely supplanted one ambiguity for another: the "collective" for the "rural collective economic organization." As lawyer 
Li Jing duly noted:

"[T]he Property Law (...) and other laws have made stipulations about the rural collective economic organization, but these stipulations have not, unclearly or inconsistently, defined the rural collective economic organization's concept, nature, functions, and forms ( $\mathrm{Li}, 2009$, p.529)."

The rural collective economic organization originates from the collectivist times when communes, brigades and production teams were administrative as well as economic units responsible for agricultural supply, planning, and production. ${ }^{42}$ Following the commune's demise, the organization's main economic function was reverted to farm households, consequently resulting in the rural collective economic organization becoming a meaningless concept. On the local level, Guangdong Province has made the greatest strides in clarifying matters and clearly stipulated that "what is designated (...) as the rural collective economic organization, refers to the people's commune, the production brigade and the production team" (Article 3 in Li, 2009, p.531).

Beijing Municipality, on the other hand, circumvents discussing the revival of previous concepts and approaches matters from the collectives' current function. In its "Measures for the Registration of Rural Collective Economic Organizations", it lists what are lawfully considered as rural collectives. Subsequently, preconditions for legal recognition and registration are described. ${ }^{43}$ Considering the ambiguity surrounding collective ownership, it is significant that one regulation determined that “independent public institutions under rural collective economic organizations need (...) not submit ownership permits of collective assets, but [can suffice with] use

\footnotetext{
42 This is also relevant for the People's Commune's predecessor, the Higher Agricultural Production Cooperatives, which were established in 1956. For more information on the period preceding the communes as well as the changes in property rights that occurred, see (Ho, 2005, pp. 5-6).

43 These are, respectively, the "town/township collective economic organizations; village collective economic organizations; farmers' specialized cooperative economic organizations; and independent public institutions (duli hesuan shiye danwei) under rural collective economic organizations" (Li, 2009: 531). For legal recognition, these organizations must "submit their statutes, copies of ownership permits of collective assets, and copies of identity cards of legal representatives" (Ibid.).
} 
permits of collective assets. ${ }^{44}$ Thus, an option born out of pragmatism has been made available for collectives to assume economic functions without proven ownership.

As ascertained from the previous information, it is evident that the debate regarding collective ownership currently continues. Moreover, it is also obvious that no overarching solution can be conceptualized; the resolution of collective ownership will eventually occur with a locally negotiated compromise that differs in time and space.

4.1.2. State owned land. As indicated previously, the land in cities is, by law, state-owned. In addition, state-owned land also comprises mineral resources, forests, grasslands, wasteland, and other natural resources with the exception of those resources belonging to collectives (Revised Constitution, article 9 in NPC, 2004). The Constitution's stipulation is of significant relevance as it signifies that the burden of proof rests with the collective and not the state. ${ }^{45}$ This would not have been problematic if it were not for the fact that collective ownership is ambiguous and, consequently, difficult to prove. Ergo, mineral resources, forests, grasslands and wasteland are virtually, by definition, state-owned. ${ }^{46}$

Matters become even more problematic with the realization that state ownership is also disputed between various levels of administration; respectively divided into central government (zhongyang zhengfu); provinces/municipalities under the State Council (zhixiashi, i.e. Beijing, Shanghai, Tianjin, Chongqing); prefectures/municipalities (diqu/shi); and counties (xian). As a result, local government - particularly, the county - can readily appropriate rights to grassland, forest, wasteland and mineral resources on behalf of the state. In order to control local

\footnotetext{
${ }^{44}$ It is added that "qualified organizations also need to register as a corporate legal person with the industrial and commercial management department" (cited in Li, 2009: 531).

${ }^{45}$ Note that this is different from the Constitution's stipulation on land in rural and suburban areas; housing land (zhaijidi); and privately farmed plots of cropland and mountainous land (ziliudi/shan), which are deemed as belonging to collectives unless proven otherwise (Revised Constitution, article $10)$.

46 This poses problems, especially when customary or historical claims are involved. In this regard, it is important to recognize that forests, grasslands and wasteland as well as a major proportion of China's mineral resources are actually located in border regions inhabited by ethnic minorities and former colonists that reclaimed the land for agriculture.
} 
government's control over land, the 1984 Land Administration Law was revised in 1998 to determine that "the right of ownership of state-owned land is exercised by the State Council as representative of the state. ${ }^{, 47}$ In addition to this, the Legal Affairs Work Committee of the National People's Congress issued a formal legal interpretation that "the various levels of local government are not the representatives for the ownership of state-owned land. They have no right to deal with state-owned land without authorization" (Legal Affairs Work Committee, 1998, p.68).

However, even after this revision, the county - as the nexus where local government functions converge - currently continues to play a decisive role in land matters. For instance, a study by Lin ascertained that, in 2002, (four years following the revision of the Land Administration Law) approximately 50 percent $^{48}$ from a total of 18.100 ha of illegal land conversions had been approved by the county (Lin, 2009, pp.97-98). The contention between the natural village versus the administrative village (and in some cases, the township) ${ }^{49}$ and the ambiguity regarding state ownership form the legacy that the reform state inherited under Deng Xiaoping. It is on these contested, institutional fundaments that titling must proceed.

\subsection{Fragmented authority over land}

The second "battleground" around which substantive bargaining between actors occurs is the fragmentation of authority over land administration. Tsinghua University vice-dean and law professor, Cheng Xiao, stated in an interview:

\footnotetext{
47 At the same time, it clarifies that "the responsible department for land administration of the State Council [i.e. the Ministry of Land Resources, PH] is uniformly charged with the management and supervision of the nation's land." See Articles 2 and 5 in the 1998 Revised Land Administration Law, in (Fang, 1998: 207).

48 More precisely, the county was the government level which approved illegal land conversion in $49.55 \%$ of the cases.

${ }^{49}$ Illustrative is also the court case of a natural village versus the local state (Xiangyang county) in Hubei Province. In the past, the land of this village had been expropriated so that the commune could construct a water reservoir. Following decollectivization, the land became state (county) property with the argument that the natural village could not legally own land. However, the county court ruled that the expropriation was illegal as the natural village, by law, enjoyed the original land ownership (Supreme Court 1997, 341-7).
} 
"The main flaw of today's titling system is that the organization for titling is not unified. (...) As organizations are different, their procedures are different, and the required titling materials are different as well; this not only drives up transaction costs, but also poses great legal risks when they are mutually linked" (Cheng Xiao cited in Song, 2013, p.20).

4.2.1. Who is responsible for what? The fragmented authority over land administration has agitated the Chinese state for an extensive period of time. In 1986, the newly proclaimed Land Administration Law (currently under revision) made two significant, yet entirely contradictory, stipulations:

Article 5 designated the State Land Administration - now the Ministry of Land and Resources - as the sole authority in the simultaneous unified administration and supervision of land resources;

$>$ Article 9 determined that additional land resources - i.e. forest, grassland, and wasteland - would be addressed with separate laws. ${ }^{50}$

The latter stipulation thus codified a historically cultivated situation in which land administration was, and still is, completely dissipated over various state departments (see Table 2 below).

Table 2: Authority and legal basis for titling per institution

\section{[Insert Table 2 about here]}

More simply stated, the Ministry of Land and Resources is responsible for titling ownership of collective land and use rights of state-owned land (employed by state and collective units or individuals). The State Bureau of Forestry is responsible for registering use rights of forest areas. Confusingly, the responsibility over use rights to

\footnotetext{
${ }^{50}$ Freshwater and saltwater fisheries and the embankments around fisheries would be addressed by the Fishery Law and thus respectively by the State Oceanic Administration (since 1998 part of the Ministry of Land and Resources) and the Ministry of Agriculture.
} 
wasteland is the responsibility of either the Ministry of Agriculture or the State Bureau of Forestry contingent upon how wasteland is defined: "forested grassland" or "grassy forest". The Ministry of Agriculture, however, continues to be responsible for the use rights of collective land and use rights to grassland. ${ }^{51}$ Some maintain that, in essence, the Ministry of Land and Resources rules the cities, and the Ministry of Agriculture rules the villages. Fragmentation of authority becomes painfully apparent on the local level as evidenced by the difficulties in coordinating titling as an inter-departmental commitment and, as a result, decelerates implementation and causes problems of multi-permitting.

For instance, regarding the titling of housing land, a local land administration department complained:

"Some regional and town governments do not attach importance to this work, and believe the titling and issuance of permits for rural housing land is just a matter of the Ministry of Land and Resources alone" (Haikou Municipality, 2011; see also CNTV Net 2011).

Other government agencies also wrote to the National People's Congress:

"The province (...) has issued forest permits, but the greater part of forest has been occupied by individuals, townships, village collective economic organizations and local governments which, in some cases, have also been issued land permits (...). The Land Administration Law should bring the forest and land permits in line with each other" (proposal to the NPC, in Heilongjiang Forestry Bureau. 1998, 352).

To facilitate "unified land administration", the State Land Administration was promoted to ministerial level in 1998 while the Ministry of Forestry was denigrated to the State Bureau of Forestry. This facilitated the advancement of the new Ministry of

\footnotetext{
${ }^{51}$ Two units within the Ministry of Agriculture - the Grassland Section (caoyuanchu) and the Grassland Monitoring Station (caoyuan jianlizhan) - are respectively responsible for grassland law and policy-making as well as the enforcement of policies and laws.
} 
Land Resources to be able to exercise national authority over land as it had been legally designated. Otherwise stated, it could better counterbalance the authority of the Ministry of Agriculture (which mainly controlled rural land) ${ }^{52}$ and the former Ministry of Construction (which controlled urban housing). Interestingly, the Ministry of Construction was renamed the Ministry of Housing and Urban-Rural Development in 2008, which expanded its authority to rural areas.

4.2.2. Titling rural lease. The agricultural lease system or the Household Contract Responsibility System (chengbao zerenzhi) has played a major role in China's development (Svejnar and Woo, 1990; Peng, 1995; Ho et al., 2004). In fact, the Chinese economic reforms began in agriculture which is the reason that additional discussion is devoted here. The agricultural lease system replaced the commune's collective organization of planned production in the mid 1980s. Instead, individual farm households were permitted to lease agricultural land from the collective. ${ }^{53}$ Despite extensive efforts by the Ministry of Agriculture to establish a unified, formal system of agricultural lease contracts, the initiative has been mostly in vain.

In the late 1970s and early 1980s, the agricultural lease system emerged as a local institutional innovation in reaction to the failure of the People's Communes. ${ }^{54}$ At this time, the lease was terminated between the rural collective and farmers through simple, hand-written contracts which lacked fundamental terms such as an unambiguous description of rights and duties of the lessor and lessee. Additionally, the contracts were not issued to individual households but, instead, as single contracts to all villagers or, if there were individual contracts, uniformly retained by the village. ${ }^{55}$

\footnotetext{
52 More specifically, land for agricultural purposes, rural housing land, rural construction land and grassland but not forest (for which the State Bureau of Forestry is responsible).

53 As indicated above, in most cases, the administrative village and not the original owner, the natural village, acted as the lessee.

54 The current agricultural lease system began as a local experiment by the Xiaogang village, Fengyang County, in Anhui Province in 1976. However, at that time, there were various contracts in which rights over land and agricultural operation such as contracting output to the household (bao chan dao hu) and contracting labor to the household (bao gan dao hu) were returned to the farm household. The Xiaogang model, which later became the national model, advocated contracting both output and labor to the household (da bao gan). Many of these lease forms originated in the mountainous regions of provinces such as Anhui, Sichuan, Shanxi and Zhejiang (see e.g. Chen, 2002).

55 As was also the case with the lease in the Xiaogang village, see the photo of the original contract at
} 
Over the years, the Ministry of Agriculture has attempted to formalize these contracts which culminated in the renewal of lease contracts in lieu of individual, standardized, and notarized contracts. This major nationwide campaign to register agricultural leases has become known as the 1998 "Second Round of Lease" (di er lun chengbao) - the first round being the official launch of the Household Contract Responsibility System in 1984. ${ }^{56}$ However, despite the endeavour, many contracts were never issued, only partially completed, or left entirely blank (e.g. empty grid maps; empty tables clarifying quality/quantity of leased land; no boundary description). ${ }^{57}$ Furthermore, changing customs in order to issue single contracts to an entire village or to prevent local cadres from keeping an entire village's contracts proved laborious. ${ }^{58}$ In total, the number of contracts issued was minimal. Many years after the Second Round of Lease, surveys ascertained that less than half of the farmers had received a contract (e.g. Prosterman et al., 2009, p.21). ${ }^{59}$ Finally, the information in the government-issued contracts is quickly rendered obsolete as changes are often not recorded or are registered informally. ${ }^{60}$

In a recent endeavor to title rural land lease, a national pilot was initiated in 105 counties, cities and districts ${ }^{61}$ in 2013. A significant feature of the pilot is the concerted effort for collaboration between concerned ministries and departments. Chaired by the Ministry of Agriculture, a joint leading work team amalgamated five

http://www.china.org.cn/china/features/content_11778487_2.htm (accessed on June 2012). See also the photo in Appendix J (Ho 2005, 246).

56 There were regional variations in the lease at the initiation, a result of which the date of expiration also varied. However, most contracts were issued from the early 1980s until the mid-1980s, e.g. a contract that would have been issued in 1984 would thus have expired 15 years later in 1999. During the second round of leases, contracts were extended to 30 years (an additional 15 years to the original term), indicating that most would expire around 2014.

57 This was also the case for land ownership contracts, see Appendices C and D in (Ho 2005, 212-225).

58 The same local custom also affected the efforts of the Ministry of Land and Resources to title collective land ownership. As a notice warned: "Land permits must be issued to the hands of the rights holder; it is strictly prohibited to withhold these under the pretext of a uniform administration (Ministry of Land and Resources et al. 2011)."

59 The survey by Ho was conducted among 1,140 farm households in 24 provinces and autonomous regions. Of the interviewed farmers, 48 percent stated they had a contract; 29 percent indicated that they had not been issued one; 12 percent said it was lost, or they could not find it; while, in 5 percent of the cases, the contract was retained by the villagers' committee (Ho 2008, 221). In a survey of 1,773 households in 17 provinces, Prosterman et al. (2009) ascertained that only 43.1 percent of the respondents had been issued a contract.

60 Villages generally retain an informal land record for their own purposes.

61 Including Pinggu District in the Beijing Municipality. 
other state agencies, i.e. the Ministry of Finance, the Ministry of Land and Resources, the CCP Agricultural Office, the State Council Legal Affairs Office, and the State Archives (National Leading Work Team, 2013).

\subsection{Land versus housing}

The third parameter of importance in the dynamics of, and bargaining over, land titling is the separate registration of housing and land. Whereas the ownership of urban housing is registered by the Ministry of Housing and Urban Rural Development (MoHURD), the use rights of urban land and ownership of rural housing land are registered by the Ministry of Land and Resources (see Table above).

4.3.1. Rural property. The registration of ownership of rural housing is ambiguous. During the Maoist and early reform period, farmers were allowed to own only one house per household. The collective granted the households the use right to a plot of rural housing land (zhaijidi) which could be employed for private purposes without paying rent, i.e. a type of "rural social housing". Registration was deemed unnecessary because the land belonged to the collective, and anyone within the close-knit village community knew who owned which house and on what land it was located (Zhang 2005). The principle of "one household, one house" (yihu yizhai) was codified in the 1998 Revised Land Administration Law (article 62).

With the onset of reforms, farmers increasingly migrated to cities, while the countryside urbanized. As a result, a legal twilight zone emerged in which rural property reserved for private use was sold illegally to urban and foreign investors. As land was acquired at no cost (from the collective), substantive profits could be accumulated which attracted investors into the market. Additionally, farmers devised ways to increase the size of their property by securing more than one plot per household ${ }^{62}$ or by defying local regulations

\footnotetext{
${ }^{62}$ For instance, this could be accomplished by making use of ambiguity around the entitlement to housing land by (unmarried) children or upon divorce (filed for economic reasons).
} 
and enlarging their property (by encroaching on their own farm land). ${ }^{63}$ The housing sold in this manner has popularly become known as "small property rights housing" (xiao chanquan fang), i.e. without full ownership.

Another type of "small property housing" results from urban sprawl. Due to the significant demand for land within rapidly expanding cities, rural land was (and still is) illegally expropriated below market prices and developed for urban real estate (Whiting, 2011). However, even though the use of certain land has shifted from agricultural land to urban construction land, its ownership remains, more often than not, as a rural collective ownership. This indicates that the newly developed real estate is illegally constructed on land that does not belong to the city and, in fact, was reserved for agriculture. This situation frequently occurs on the rural-urban fringe. ${ }^{64}$

Over the previous years, clandestine, yet lucrative, markets for "small property rights housing" have flourished at the rural-urban frontier. However, by spring 2012, the Ministry of Land and Resources had more forcefully regulated the sale of "small property rights housing”. A first crucial, but excruciatingly, complicated step in this national "clean up" campaign is to ascertain how rural housing property is registered, if at all, and to subsequently determine the authority over its titling (Ministry of Land and Resources 2012; Anonymous 2012).

4.3.2. Urban property. As was previously indicated, state-owned land is not registered. As a consequence, ownership of urban land is also not registered. However, China does register ownership and use of urban real estate, though this is registered by different departments. Whereas the rural collective provided its members with social housing, the urban work-unit (danwei) did the same for its workers during the Maoist and early reform periods. ${ }^{65}$ Since the housing reform in 1998, work-units began to sell the housing that had been built between the 1950s and 1980s at below market

\footnotetext{
${ }^{63}$ Each province and locality stipulates specific norms regarding the area of rural housing land for use by each farm household.

${ }^{64}$ In Beijing, examples of this illegal real estate are Hongfuyuan, a well-known area of small property rights housing located in the Changping district as well as Shigezhuang or Baigexin Village.

${ }^{65}$ In Chinese, this is indicated as the policy of housing allocation (fen fang) by the work-unit. In addition to housing, the work units also provided a wide range of other services including pension, disability and health insurance, and sometimes education (through schools run by the work unit).
} 
prices to employees. Over the past decade, employees often resold this housing in order to buy new property that was developed by private and (state) real estate companies. At the same time, work-units themselves also engaged in the construction of new property.

Currently, work-units are still evident - and particularly, larger, state-run units, e.g. state companies, universities, and government departments - that own and allocate housing that comprises a significant component of an employee's benefits package. ${ }^{66}$ The main variance with the collectivist past is that housing is no longer provided at no charge but, instead, long term, non-marketable use rights are purchased. Thus, the use right cannot be sold but can be inherited. However, the term of use is uncertain, and it is also uncertain if it can be inherited by third generation descendants as that situation has not yet occurred. It is significant to distinguish between privately owned real estate versus housing provided by work-units because ownership to the former is registered by the Ministry of Housing and Urban-Rural Development, whereas the non-marketable, long term use right to the latter is registered by the work-unit. ${ }^{67}$

\subsection{Towards unified titling?}

In light of all of the above, 2013 appeared a memorable year. The State Council, in its annual plan on the government structure, called for the "unification of responsibilities over the titling of housing, forest, grassland, land, and others" (State Council, 2013) ${ }^{68}$ To accomplish this, a separate agency would need to be established: a cadaster. The

\footnotetext{
${ }^{66}$ Major academic institutions such as the universities of Tsinghua and Peking own substantive property assets for staff. For instance, the expensive Weibohao compound in Haidian district has an entire block designated for Peking University staff, while Tsinghua University acquired new land for property development through the expropriation in 1997 of $300 \mathrm{mu}$ of land from the Dashiqiao village of the former Xiyuan Production Brigade in Haidian district. State ministries also own property such as Building 6 at Zhongguangcun South Avenue 22 which is partially owned by the Ministry of Agriculture and the Ministry of Science and Technology.

${ }^{67}$ There are various feasible situations. For instance, the work-unit sells the use right to an employee, who subsequently obtains a permanent, inheritable but non-marketable use right. In this case, the transfer of use right is usually recorded by the work-unit. The work-unit can also sell ownership, in which case the deed transfer will be recorded by the Department for Housing under the Ministry of Housing and Urban-Rural Development.

${ }_{68}$ The "Central Office for Organization and Personnel" (zhongyang bianban) was charged with this task.
} 
deadline set for this work was the end of April of that year. Roughly a year later, a senior official of the Ministry of Land and Resources mentioned:

"The Real Estate Registration Agency is currently being established. In fact, it is one unit with two placards (yige danwei, liangge paizi). The Directorate General for Titling Administration is changed into the Real Estate Registration Agency. But personnel also needs to be increased, which occurs by transferring people from other departments. To date there are over ten." ${ }^{\circ 9}$

To provide a regulatory basis for "unified titling" the State Council also proclaimed the Provisional Measures on Real Estate Registration effective since March 2015. However, close to three decades ago, Chinese law already unequivocally stipulated that "the land management department under the State Council is responsible for the unified administration of land resources" (Article 5, 1986 Land Administration Law). This might be a reminder that processes of institutional change take a long period in gestation, and have everything to do with battlegrounds of bargaining. Or, as a Chinese commentator duly noted:

Advancing registration of real estate and setting up a unified information network must break vested interests (...). It is clear that furthering the registration of real estate needs courage and force (Luo, 2013).

\section{State intentions versus outcomes: Concluding observations}

The initial national rules regarding registration were enacted in 1922. However, the Chinese state's endeavors for institutional change through titling have never materialized. This implies that the recent phenomenal growth in land and real estate has occurred in the absence of legally protected and secure property rights. In spite of

\footnotetext{
${ }^{69}$ Oral communication, interviewee SYH-25/3/14, Director General of Land Law Centre, Ministry of Land and Resources, 25 March 2014.
} 
elevated political urgency and support by the CCP Central Committee, it does not appear as though China's grand engineering project of titling can be completed soon. This article has demonstrated that institutional change of titling involves actors' protracted negotiation over three sources of conflict. These relate to the ambiguous nature of collective and state ownership; the divided and conflicting authority over land policy; and, lastly, the divided administration of land and housing. In this aspect, it was posited that the completion of a cadaster is the final resultant of development rather than its precondition. This postulate stands in stark contrast with neo-liberally inspired concepts and theories of development and titling (e.g. Ellickson, 2012; Palomar, 2002; Micelli et al., 2000; De Soto, 2000).

Stein (2012, p. 4) described Chinese real estate and land development as a situation in which "[r]eal estate developers are building award-winning office towers, modern shopping malls, and five-star hotels, and tens of millions of urban families are scraping together the money to buy their own apartments." China's rapid urbanization has also concurrently stimulated increasing conflict over land and housing. ${ }^{70}$ For this reason, demands for legally protected property rights have reverted in full force with many fearing that the acceleration of titling is too slow, hence, China might face socio-economic destabilization. Paradoxically, the central state's increasingly ambitious goals for titling - registration of all rural, collective land by 2013 (CCP Central Committee and State Council 2010, p.5) - has led to the establishment of “empty institutions" (Ho, 2005, p. 73) as titles were issued only in name or not at all. In addition, titling itself has created conflict, forcing the state to continuously postpone and readjust its plans. As the Vice-Director of the influential Information Centre of the Ministry of Land and Resources stated: "Once you start titling, conflicts that were dormant flare up again."71 This description might be particularly true for the titling of rural collective land and, in fact, explains why titling never fully proceeded to the original land owner, the natural village. An official communiqué of

\footnotetext{
70 In 1993, China experienced 8,709 incidents related to peasants' (i.e., land disputes) and workers' unrest. By 1999, these conflicts had quadrupled to over 32,000. Six years later, they had again tripled to reach 87,000 (Chinese Academy of Social Sciences, 2005).

${ }^{71}$ Oral communication, interviewee LXB-27/6/13, Vice-Director, Information Centre, Ministry of Land and Resources 27 June 2013.
} 
the Ministry of Land and Resources reported that:

"The issuance of permits is still very low while the permits for rural collective ownership, in most cases, only assess the land rights at the level of the administrative village and not for every rural collective with ownership" (Ministry of Land and Resources 2011, italics added).

As perceived by the central state, the challenge for titling becomes one in which the government must mitigate illegal shifts in ownership, or it must deliver justice to forced expropriations with the risk of opening a Pandora's Box of conflict. To many, this appears as a devilish dilemma. Some within the Ministry of Land and Resources have, therefore, championed to leave land titling voluntary. A high official stated:

"The Ministry of Land and Resources favors voluntary titling: once land has been titled, it is legal, but conversely, when it has not been titled it is not necessarily illegal. However, there is a lot of debate and (...) this issue has not been solved yet." 72

Others, on the other hand, argue that specific circumstances should be identified under which titling should not occur:

"When there are illegal land deals, titling should not proceed. Instead, the situation should be examined and explained in the work report at the end of the year" (Henan Provincial Land Administration 2009).

The dilemma of titling versus non-titling could be resolved in additional ways. For one, the state could register without legitimizing by introducing a "negative, causal

\footnotetext{
${ }^{72}$ Literally: $b u$ dongchan dengji fa. Oral communication, interviewee ZL-2/10/07, Vice-Director General Land Titling, Ministry of Land and Resources, study visit on Dutch land registration and spatial planning hosted by ProLAND project, 2 October 2007. Interviewee is currently General Inspector of the Jinan Region of the Ministry of Land and Resources.
} 
system" of titling as, for instance, exists in The Netherlands. The negative nature of titling implies that registration is a precondition for ownership, yet, if one's property is registered, it does not automatically entail ownership. The causal nature of the system indicates that, if property has been appropriated illegally, ${ }^{73}$ the sale will be voided. ${ }^{74}$ The negative, causal system of titling protects the lawful owner while still allowing maneuvering space for titling to continue. ${ }^{75}$ Second, the state could codify the passage of time in order to solve conflict. ${ }^{76}$ In this manner, a person can automatically become a landowner if no formal appeal is lodged during a period of 20 or 30 years regardless of whether the property has been titled or not (Van Es, 2011).

Some have wondered why China's land titling has been so difficult. The question has been explained by investigating the bargaining around institutions of which this article is but an example, albeit a crucial one, when land as means of production is addressed. In this perspective, the state is just one of many social actors that shapes and negotiates institutions. It is worth mentioning that the state is no monolith but should be analytically divided into various actors, sectionalized between ministries and agencies at various levels. As a result of bargaining, the state is not an external enforcer of institutions but exists as one of the endogenous participants in the "game." As such, titling as an institutional intervention becomes part of a long and autonomously driven process of negotiation and disputes that ultimately shapes it into a form corresponding to the function that social actors accord to it. Disregarding that principle by aiming to push through land registration - regardless whether that is done for reasons of efficiency, transparency, or the rule of law - bears an inherent risk. ${ }^{77}$

\footnotetext{
73 Appropriation is only legal when three conditions have been met: i) there is a title, i.e. there is an agreement to sell between the buyer and seller; ii) the seller is entitled to sell, i.e. he has not illegally obtained the property he is selling; and iii) there is an act of transfer, i.e. the property has changed hands from seller to buyer.

${ }^{74}$ However, this also indicates that the buyer incurs an increased risk of closing a deal that might be annulled if the property was illegally acquired. To compensate for this risk, an extra safeguard has been built into the Dutch system through the requirement that all rights and information of property must be examined by the notary prior to the sale.

${ }^{75}$ The Dutch negative, causal system of land titling was established and officially confirmed by a ruling of the Dutch Supreme Court 80 years following the introduction of the first Dutch Civil Code in 1838. Leon Verstappen, oral communication, professor in Dutch Notary Law at the University of Groningen, 3 October 2007.

${ }_{76}$ Also known as the principle of acquisitive prescription ("verjaring" in Dutch).

77 As also pointed out by (Rowton-Simpson, 1976, p. 3) and for the Chinese case by (Tao and Wang,
} 
Having said this, it is not to deny that the cadaster can have important socio-spatial and distributional consequences, nor is it to negate the purpose and possibility of institutional intervention. Yet, it does imply that time - and more specifically, the sequence of institutional change - is crucial in understanding the consequences of a cadaster. Governments might be able to better foresee the potential outcomes of their policies if existing functions of institutions are grasped prior to the consideration of intervention, or non-intervention. In other words, governments can only then hope to make an institutional difference when they have thoroughly fathomed how time might relate to the functionality and credibility of "institutions in use" versus institutions they aspire.

\section{Acronyms}

$\begin{array}{ll}\text { CCP } & \text { Chinese Communist Party } \\ \text { MLR } & \text { Ministry of Land and Resources } \\ \text { MoCA } & \text { Ministry of Civil Affairs } \\ \text { MoA } & \text { Ministry of Agriculture } \\ \text { MoHURD } & \text { Ministry of Housing and Urban Rural Development } \\ \text { NPC } & \text { National People's Congress } \\ \text { SBF } & \text { State Bureau of Forestry }\end{array}$

\section{References}

Aoki, Masahiko (2007), "Endogenizing Institutions and Institutional Changes", Journal of Institutional Economics, Volume 3, Issue 01, April, pp 1 - 31

Anonymous (2012), "Qianxi Nongcun Budongchan Dengji Zhidu Yanjiu" [An elementary analysis of the rural registration system of real estate]. 25 May, at http://www.starlunwen.net/faxue/92284.html 
Buck, John Lossing (1930), Chinese Farm Economy: A study of 2866 farms in seventeen localities and seven provinces in China. Shanghai: The Commercial Press Ltd.

Cai, Yongshun (2003), “Collective ownership or cadres' ownership? The non-agricultural use of farmland in China", The China Quarterly, Issue 175: 662-680

CCP, (1962), “Nongcun Renmin Gongshe Gongzuo Tiaoli Xiuzheng Cao’an” [Revised Draft of the Work Regulations of the Rural People's Communes] 27/9/1962, in Zhongguo Renmin Jiefangjun Guofang Daxue Dangshi Yanjiushi (ed.), Zhonggong Dangshi Jiaoxue Cankao Ziliao [Reference and Educational Material on the History of the CCP], Vol. 23 (Beijing: Guofang Daxue Chubanshe, 1986), p. 137

CCP (1961), 'Nongcun Renmin Gongshe Gongzuo Tiaoli Cao'an"' ['Draft of the Work Regulations for the Rural People's Communes'], March 1961 in Zhongguo Renmin Jiefangjun Guofang Daxue Dangshi Yanjiushi (ed.), Zhonggong Dangshi Jiaoxue Cankao Ziliao [Reference and Educational Material on the History of the CCP], Vol. 23 (Beijing: Guofang Daxue Chubanshe, 1986), p. 454

CCP Central Committee (2008), “Zhonggong Zhongyang guanyu tuijin Nongcun Gaige Fazhan ruogan Zhongda Wenti de Jueding" [Decision on Several Major Issues of Rural Reform and Development], adopted 12 October 2008, third plenary session of the $17^{\text {th }}$ Central Committee Communist Party Congress of China

CCP Central Committee and State Council (2010), "2010 nian zhongyang yihao wenjian: zhonggong zhongyang, guowuyuan guanyu jiadao tongchou chengxiang fazhan lidu jinyibu hangshi nongye nongcun fazhan jichu de ruogan yijian" [Number One Central Document of 2010: Some suggestions by the CCP Central Committee and State Council on the increase of urban and rural development efforts to further 
consolidate the basis of agricultural and rural development] (December 31, 2009), officially released on 31 January 2010, pp. 1-7, available at http://news.xinhuanet.com/politics/2010-01/31/content_12907829.htm

CCP Central Committee and State Council (2013), “2013 nian zhongyang yihao wenjian: zhonggong zhongyang guowuyuan guanyu jiakuai fazhan xiandai nongye jinyibu zengqiang nongcun fazhan huoli de ruogan yijian" [Number One Central Document of 2013: Some suggestions by the CPC Central Committee and State Council on accelerating the development of modern agriculture that further enhance the vitality of rural development], 31 January 2013, pp. 1-4, available at http://www.gmw.cn/xueshu/2013-02/05/content_6635517_3.htm

CCP Central Committee and State Council (2013), "2013 nian zhongyang yihao wenjian: zhonggong zhongyang guowuyuan guanyu jiakuai fazhan xiandai nongye jinyibu zengqiang nongcun fazhan huoli de ruogan yijian" [Number One Central Document of 2013: Some suggestions by the CPC Central Committee and State Council on accelerating the development of modern agriculture that further enhance the vitality of rural development], 31 January 2013, pp. 1-4, available at http://www.gmw.cn/xueshu/2013-02/05/content_6635517_3.htm

Chang, Ha-Joon (2007), Institutional Change and Economic Development. Tokyo, New York, Paris: United Nations University Press

Chen, Chien-Hsun (2002), "Property Rights and Rural Development in China's Transitional Economy", Economics of Planning, 2002, Vol. 35, No. 4, pp. 349-363

Chinese Academy of Social Sciences (ed.) (2005), Blue Book of China's Society: Analysis and Forecast on China's Social Development, Beijing: Social Sciences Academic Press 
Chovanec, Patrick (2012a), BBC: China's 2011 GDP Numbers. Patrick Chovanec: An American Perspective from China. January 17. at http://chovanec.wordpress.com/2012/01/17/bbc-chinas-2011-gdp-numbers/

Chovanec, Patrick (2012b), Further Thoughts on Real Estate's Impact on GDP. Patrick Chovanec: An American Perspective from China. January 20. at: http://chovanec.wordpress.com/2012/01/20/further-thoughts-on-real-estates-impact-o $\underline{\text { n-gdp/ }}$

Clarke, Donald (2014), “China's Stealth Urban Land Revolution”, American Journal of Comparative Law, Vol. 62, No. 2, pp. 323-366

CNTV Net (2011), "Tigao renshi gongjian kenan baozhi baoliang wancheng renwu", [Increase Awareness, Overcome Problems, and Safeguard Quality in Completing Duties], CNTV Net, 21 June, original source: Haikou Wang, at http://news.cntv.cn/20110621/108959.shtml, accessed on 8 June 2012

Commons, J. R. (1961), Institutional Economics. Madison: University of Wisconsin Press.

Dale P.D. and McLaughlin, J.D. (1988), Land Information Management Oxford : Clarendon Press.

De Soto, Hernando (2000), The Mystery of Capital: Why Capitalism triumphs in the West and fails everywhere else. New York: Basic Books.

Demsetz, Harold (1967), 'Toward a Theory of Property Rights', American Economic Review, Vol. 62, pp. 347-59

Dowson, Ernest K.B. and V.L.O. Sheppard (1956), Land Registration, London: H.M. 
Stationary Office

Ellickson, Robert C. (2012), “The Costs of Complex Land Titles: Two Examples From China”, Faculty Scholarship Series. Paper 3604, Yale Law School, pp. 1-23, at http://digitalcommons.law.yale.edu/fss_papers/3604/

Fang, Weilan. (ed.) (1998), "Zhonghua renmin gongheguo tudi guanlifa shiyong jianghua" [A Practical Discussion of the 'Land Administration Law of the People's Republic of China], Beijing: Zhongguo Minzhu Fazhi Chubanshe

Flannery, Russell (2003), “China's 100 Richest 2003”, Forbes, at http://www.forbes.com/2003/10/29/chinaland.html, accessed on 2 August 2007

Grabel, Ilene (2000), “The political economy of 'policy credibility': the new-classical macroeconomics and the remaking of emerging economies" Cambridge Journal of Economics, 24 (1), pp. 1-19

Gray, Jack (1990), Rebellions and Revolutions: China from the 1800s to the 1980s. Oxford: Oxford University Press.

Haikou Municipality (2011), "Haikou nongcun zhaijidi quequan dengji fazheng jihua shi yuefen jieshu" [Haikou: Plan for the Issue of Permits for Titling Rural Housing Land Completed by October], Haikou Wanbao, 21 June, available at http://www.hq.xinhuanet.com/house/2011-06/21/content_23061693_1.htm accessed on 8 June 2012

Heilongjiang Forestry Bureau (1998), "Heilongjiang sheng youguan bumen, zhuanjia he jiceng zuzhi guanyu 'tudi guanlifa' (xiuzheng'an) de yijian" [Remarks on the 'Land Administration Law (Revised Draft)' by Relevant Departments, Several Experts and Grassroots Units of Heilongjiang Province'"], in NPC Legislative Work Committee (ed.). 
1998. Zhonghua Renmin Gongheguo Tudi Guanlifa Shiyi [An Interpretation of the Land Administration Law of the People's Republic of China]. Beijing: Falü Chubanshe.

Henan Provincial Land Administration (2009), "guanyu zuohao nongcun jiti tudi dengji gongzuo de tongzhi" [Notice on doing well the work of rural collective land titling], Notice No. 33, March 16

Ho, Peter (2013), "In Defense of Endogenous, Spontaneously Ordered Development: The Institutional Structure of China's Rural Urban Property Rights", Journal of Peasant Studies, Vol. 40, No. 6, 1-32

Ho, Peter (2005), Institutions in Transition: Land Ownership, Property Rights and Social Conflict in China. Oxford: Oxford University Press

Ho, Peter, Jacob Eyferth, and Eduard B. Vermeer (2004) (eds.), Rural Development in Transitional China: The New Agriculture, (New York: Routledge)

Ho, Peter (2000), “The Myth of Desertification at China's Northwestern Frontier (1929-1960)", Modern China, Vol. 26, No. 3, pp. 348-395

Honoré, A.M. (1961) 'Ownership', in Guest, Anthony G. (ed.) Oxford Essays in Jurisprudence Oxford: Oxford University Press), pp. 107-47

Hoogewerf, Rupert (2002), “China's 100 Richest 2002”, Forbes, at www.forbes.com/lists/2002/10/24/chinaland.html accessed on 2 August 2007

Hsing Y.T. (2010), The Great Urban Transformation: Politics of Land and Property in China. Oxford: Oxford University Press.

Hu, Chuanrong (2007), Zhongguo tudi diaocha yu dengji zhidu fazhan yu xianzhuang 
[diaocha bufen], [Development and Current Situation of the Land Survey and Registration System in China - Research Section], 2007, January conference, available at http://www.landregistry.ie/uploadedfiles/conference20071/papers/China_paper.pdf, accessed on 9 April 2012

Hu, Cunzhi (1998) (ed.), Tudi Dengji Lilun yu Fangfa (Theory and Methods of Land Registration), Vol. I, Beijing: Zhongguo Nongye Chubanshe

Inglehart, Ronald (1997), Modernization and Postmodernization: Cultural, Economic, and Political Change in 43 Societies. Princeton: Princeton University Press.

Knight, Jack (1998), Institutions and Social Conflict. $4^{\text {th }}$ edition. Cambridge: Cambridge University Press.

Kung, James, Yongshun Cai and Xiulin Sun (2009), "Rural cadres and governance in China: incentive, institution and accountability", The China Journal, No. 62: 61-77

Legal Affairs Work Committee (ed.) (1998), Zhonghua Renmin Gongheguo Tudi Guanlifa Shiyi [An Interpretation of the Land Administration Law of the People's Republic of China]. Beijing: Falü Chubanshe.

Li, Jing (2009), "Wo guo nongcun jiti jingji zuzhi falü diwei fenxi” [An analysis of the legal status of the rural collective economic organization], Shanxi Nongye Daxue Xuebao (Shehuixue ban), Vol. 8, No. 5, pp. 529-531

Lin, G.C.S. (2009), Developing China: Land, Politics and Social Conditions. London and New York: Routledge.

Liu, Xinhua (ed.) (1998), Xin Tudi Guanlifa Quanshu [Encyclopedia of the New Land 
Administration Law], Vol. I. Beijing: Zhongguo Wujia Chubanshe.

Luo, Bote (ed.) (2013), "Budongchan tongyi dengji zhidu tuijin mianlin liang da zuli", [Advancing a unified real estate registration system faces a large, dual resistance], China.com, 23 November, at http://finance.china.com.cn/roll/20131123/1995244.shtml, accessed on 25 November 2013

Mao, Dan and Ping Wang (2004), "Cunji zuzhi de nongdi tiaokongquan" [Village-level Cadres' Rights and Control over the Distribution of Rural Land], Shehuixue Yanjiu, 6, pp. 41-51

Micelli, Thomas J., C.F. Sirmans and Geoffrey K. Turnbull (2000), “The Dynamic Effects of Land Title Systems", Journal of Urban Economics, No. 47, pp. 370-389

Ministry of Land and Resources (2007a), Tudi dengji banfa [Measures on Land Registration], Ministerial Order by the Ministry of Land Resources, Number 40, examined and adopted on 28 November 2007 by the $5^{\text {th }}$ Ministerial Meeting, effective on 1 February 2008

Ministry of Land and Resources (2007b), "Systems of Land Surveying and Registration in China”, Presentation for the ProLAND Project Board Meeting, Beijing, 2 October

Ministry of Land and Resources (2008), "Queding tudi suoyouquan he shiyongquan guiding - zhengqiu yijian gao" [Draft to Solicit Opinions on the Regulations for the assessment of land ownership and use rights], 20 November

Ministry of Land and Resources, Ministry of Finance and Ministry of Agriculture (2011), Guanyu jiakuai tuijin nongcun jiti tudi quequan dengji fazheng gongzuo de tongzhi, 
[Notice concerning speeding up and furthering the work on the assessment of land rights, titling and issue of permits], 6 May

Ministry of Land and Resources (2012,. Xiao chanquanfang zuixin zhengce jijiang mianlin bei quanmian qingli [Most recent policy regarding "small property housing, a comprehensive clean-up is imminent], 22 February, reported at http://re.icxo.com/htmlnews/2012/02/22/1406339.htm

National Leading Work Team (2013), "Nongyebu, Caizhengbu, Guotu Ziyuanbu, Zhongnongban, Guowuyuan Fazhiban, Guojia Dang'anju guanyu queding 2013 nian quanguo nongcun tudi chengbao jingyingquan dengji shidian diqu de tongzhi" (Notice by the Ministry of Agriculture, Ministry of Finance, Ministry of Land and Resources, CCP Agricultural Office, State Council Legal Affairs Office, and State Archives on Determining the 2013 Pilot Regions for the Nationwide Titling of the Rural Contract Management Right), 1 March

NPC (National People's Congress) (1982), Revised Constitution, adopted by the $5^{\text {th }}$ Session of the Fifth National People's Congress on 4 December 1982

NPC (National People's Congress) (2004), Revised Constitution, adopted by the Second Session of the Tenth National People's Congress on 14 March 2004

NPC (National People's Congress) (2007), Property Law, adopted by the Fifth Session of the Tenth National People's Congress (NPC) on 16 March, available at: http://www.lawinfochina.com/Display.aspx?lib=law\&ID=6642, accessed on 4 August 2013

NPC Legislative Work Committee (ed.). (1998), Zhonghua Renmin Gongheguo Tudi Guanlifa Shiyi [An Interpretation of the Land Administration Law of the People's Republic of China]. Beijing: Falü Chubanshe. 
North, Douglass C. and Robert Paul Thomas (1973), The Rise of the Western World: A New Economic History. Cambridge: Cambridge University Press.

Olson, Mancur (2000), The IRIS Idea: The Needed Research, Center for Institutional Reform and the Informal Sector, available at http://www.iris.umd.edu/research/neededresearch.asp, last visited 23 November 2001

Osborne, Anne (1994), "The Local Politics of Land Reclamation in the Lower Yangzi Highlands." Late Imperial China, 15:1 (June) 1-46.

Palomar, Joyce (2002), "Land Tenure Security as a Market Stimulator in China", 12 Duke Journal of Comparative \& International Law, 7-74

Peng, Zhen (1982), “Guanyu Zhonghua Renmin Gongheguo Xianfa xiugai cao'an de baogao: Daibiao Xianfa Xiugai Weiyuanhui xiang di wu jie Renda wuci huiyi suozuo de baogao" [Report on the revision of the Constitution of the People's Republic of China: Report for the Fifth Session of the Fifth Meeting of the National People's Congress on behalf of the Constitutional Revision Commission], 26 November, in Peng Zhen (1991), Peng Zhen wenxuan: 1941-1990, Beijing: Renmin Chubanshe

Peng, Yusheng, "China's Rural Enterprises: Effects of Agriculture, Surplus Labor, and Human Capital" (July 1, 1995). Institute for Social Science Research. Volume VI. 1994-95 - Biotechnology Studies. Paper 7, p. 1

Pomeranz, Kenneth (2005), "Land Markets in Late Imperial and Republican China", Paper presented for the conference The Rise, Organization, and Institutional Framework of Factor Markets, 23-25 June 2005, pp. 1-45. available at http://www.iisg.nl/hpw/factormarkets.php 
Prosterman, Roy, Keliang Zhu; Jianping Ye; Jeffrey Riedinger, Ping Li and Vandana Yadav (2009), "Secure Land Rights as a Foundation for Broad-based Rural Development in China: Results and Recommendations from a Seventeen-Province Survey", National Bureau of Asian Research, Special Report Number 18, November 2009

Quanguo Nongcun Guding Guanchadian Bangongshi (1998), “Dangqian Nongcun Tudi Chengbao Jingying Guanli de Xianzhuang ji Wenti" (The Present Situation and Problems facing the Management and Administration of Rural Land Lease), Zhongguo Nongcun Guancha, No. 5, pp. 56-7

Rowton-Simpson, S (1976), Land Law and Registration. Cambridge: Cambridge University Press.

Shen, Tsung-han (1951), Agricultural Resources of China. Ithaca NY: Cornell University Press.

Sjaastad, Espen and Ben Cousins (2009), "Formalisation of land rights in the South: An overview", Land Use Policy, January, Volume 26, Issue 1, pp. 1-9

Song, Xi (2013), “Budongchan tongyi dengji, landezhu 'fang X’?" [Unified registration of real estate, will it stop house [uncle or aunt] X?], an interview with Cheng Xiao, vice dean of Tsinghua University, Beijing Evening Paper, 18 March, p. 20

Sonius, H. W. J. (1963), Introduction to Aspects of Customary Land Law in Africa: As compared with some Indonesian Aspects. Leiden: Universitaire Pers Leiden.

State Council (2014), "Budongchan dengji zanxing tiaoli” [Provisional regulations for real estate registration], Decree No 656, 12 November, effective on 1 March 2015, at 
http://finance.china.com.cn/news/gnjj/20141222/2864424.shtml, accessed on 8 March 2015

State Council (2013), “Guowuyuan bangongting guanyu shishi 'guowuyuan jigou gaige he zhineng zhuanbian fang 'an' renwu fengong de tongzhi" [Notice of the State Council Secretariat on the Division of Labour and Tasks for the Implementation of the "Plan of the State Council's Structural Reform and Functional Change], 26 March, at http://news.xinhuanet.com/politics/2013-03/28/c 115200485.htm, accessed on 20 July 2013

State Council (1986), "Zhonghua Renmin Gongheguo Fangchanshui Zanxing Tiaoli” [Temporary Regulations on the Property Tax of the People's Republic of China], State Council Issue [1986]/90, available at http://www.gov.cn/banshi/2005-08/19/content_24823.htm, accessed on 20 July 2013

State Council (1984), “Guowuyuan pizhuan nongmuyulinbu, guojia jiwei deng bumen guanyu jinyibu kaizhan tudi ziyuan diaochao gongzuo de baogao de tongzhi” [The State Council's Notice on the Approved and Issued Report on the Further Investigation of Land Resources by the Departments of Agriculture, Animal Husbandry, Fishery and Forestry, as well as the State Planning Commission and other departments], 16 May, in Xinhua Liu (ed.), Xin Tudi Guanlifa Quanshu [Encyclopedia of the New Land Administration Law], Vol. I (Beijing: Zhongguo Wujia Chubanshe, 1998), pp. 1137-8

State Agency for Urban Construction (1982), "Guojia chengshi jianshe zongju: guanyu chengshi [zhen] fangdichan chanquan, chanji guanli zanxing guiding” [State Agency for Urban Construction on Temporary Regulations Regarding the Titling and Administration of Municipal (Town) Property and Real Estate], 27 March 1982, Notice Number 77 
State Land Administration (1987), Guojia tudi guanliju guanyu jiaqiang diji guanli gongzuo de tongzhi [Notice on the Strengthening of the Administration of Land Titling], 4 October, in Xinhua Liu (ed.), Xin Tudi Guanlifa Quanshu [Encyclopedia of the New Land Administration Law], Vol. I (Beijing: Zhongguo Wujia Chubanshe, 1998), pp.1140-1141

State Land Administration (1995), Queding tudi suoyouquan he shiyongquan de ruogan guiding [Several Administrative Regulations on the Determination of Land Use and Ownership Rights], Xinhua Liu (ed.), Xin Tudi Guanlifa Quanshu [Encyclopedia of the New Land Administration Law], Vol. I. Beijing: Zhongguo Wujia Chubanshe. 1998)

Stein, Gregory M., (2012), Modern Chinese Real Estate Law: Property Development in an Evolving Legal System, Farnham: Ashgate

Sun, Jianhong (ed.) (1998), Tudi Quanshu Shiwu Zhinan [Practical Compass on Land Title]. Beijing: Zhongguo Dadi Chubanshe.

Supreme Court (ed.) (1997), Renmin fayuan anlixuan - xingzhengjuan 1992-1996 [A Selection of Cases from the People's Courts - Volume for Administrative Cases]: 1992-1996, Beijing: Renmin Fayuan Chubanshe.

Svejnar, J., and Woo, J. "Development patterns in four counties", in: W. A. Byrd \& Q. Lin (eds.), China's rural industry: 63-80. New York: Oxford University Press, 1990

Tao, Ran and Hui Wang (2014), "Zhongguo nongcun tudi gaide de wuqu yu jinlu" [Misunderstanding and Approach of China's Rural Land Reform], Zhongguo Gaige Wang, at http://www.chinareform.net/show.php?id=20766, 23 December, accessed on 8 March 2015 
Tang, Fuchun (2007), "NPC adopts Property Law”, China.org.cn, 16 March 2007, at http://www.china.org.cn/english/2007lh/203173.htm, accessed on 22 July 2013

Thorpe, Andy (1997), 'Adjustment, agricultural modernization and land markets: the case of Honduras', in Max Spoor (Ed.), The 'Market Panacea': Agrarian transformation in developing and former socialist economies. London: Intermediate Technology Publications.

Xiang, Hongyi (ed.) (1996), Tudi Quequan Shiyong Shouce [A Practical Manual for the Assessment of Land Title]. Beijing: Zhongguo Dadi Chubanshe.

Xiao, Yulei, (2007), “Gaige kaifang yilai cunji zuzhi de nongdi tiaokongquan - dui shanxi sheng $Z$ xian baocun de diaocha yu yanjiu" [Control over Rural Land by Village-level Organizations since the Opening Up and Reforms - A Survey and Research on Bao Village in Z County of Shanxi Province], Zhongbei Daxue Xuebao (Shehui Kexueban), 2, pp. 26-20

Xu, Feng (1998), "Gufen Hezuo yu Nongye Tudi Zhidu Gaige" [Shareholding Cooperatives and the Reform of the Agricultural Land System], Nongye Jingji Wenti, No. 5, p.22

Xu, Chongde (2003), Zhonghua Renmin Gongheguo Xianfashi [A history of the Constitution of the People's Republic of China], Fuzhou: Fujian Renmin Chubanshe

Van den Bergh, Govaert C. J. J. (1996), 'Property versus Ownership: Some Cursory Notes', in Joep Spiertz and Melanie G. Wiber (eds.), The Role of Law in Natural Resource Management. The Hague: VUGA.

Van Es, P.C (2011), Ars Aequi Cahiers - Privaatrecht, verkrijging door verjaring, [Ars Aequi Cahiers - Private Law - Acquisitive prescription]. Nijmegen: Juridische 
Uitgeverij Ars Aequi.

Van Vollenhoven, C. (1909), Miskenningen van het Adatrecht [Misunderstandings of Adat Law]. Leiden: Brill.

Von Benda-Beckmann, F. (1979), Property in Social Continuity: Continuity and Change in the Maintenance of Property Relationships through Time in Minangkabau, West Sumatra. The Hague: M. Nijhoff.

Whiting, Susan (2011), "Values in Land: Fiscal Pressures, Land Disputes, and Justice Claims in Rural and Peri-Urban China," Urban Studies, Vol. 48, No. 3, pp. 569-587

Yueh, Linda (2013), China's Growth: The Making of an Economic Superpower, Oxford: Oxford University Press

Zelin, Madeleine (1986), "The Rights of Tenants in Mid-Qing Sichuan: A Study of Land-Related Lawsuits in the Baxian Archives." Journal of Asian Studies 49:3 (August) 499-526

Zhang, Fangsheng (2005), Nongcun fangwu chanquan dengji falü zhidu goushe [Design for a Legal System for the Titling of Rural Housing Property], at http://www.law-lib.com/lw/lw_view.asp?no=4655, 13 February

Zhang, Shiyong (2013), “Cunji zuzhi de nongdi tiaozheng shijian - dui Chengdu shi ZQ cun jianshe yongdi zengjian guagou xiangmu shishi guocheng de kaocha" [Practice of Rural Land Distributions by Village-level Organizations Implementation Study of the Program on Connecting the Increase of Urban Construction Land with the Decrease of Rural Residential Area of ZG Village of Chengdu Municipality], Guizhou Shehui Kexue, 4, pp. 119-225 
Zhu, Liuhua (2011), Xiaochanquanfang zuixin zhengce, guotubu yanjin dengji fazheng [New Policy on Small Property Rights' Housing; Ministry of Land and Resources Strictly Prohibits Titling and the Issue of Permits], 10 November. Available at http://bbs.taofang.com/thread-24009-1-1.html, accessed on 12 June 2012 
Table 1: Levels of Chinese administration and changes in ownership

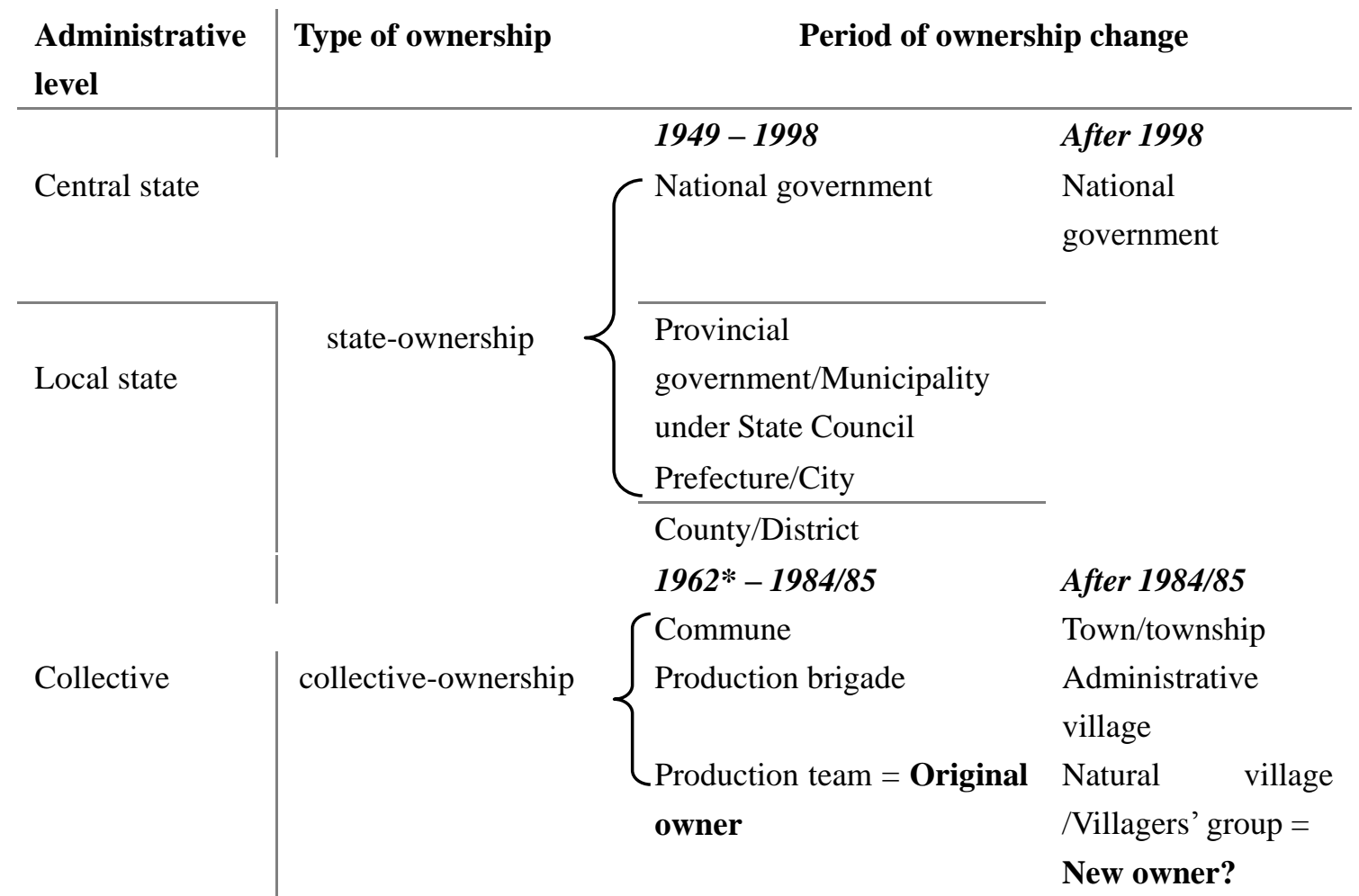

Source: Drawn by author

* Collective property changes before 1962, not shown in this table. From 1949 until the 1950-1952 Land Reform movement, agricultural land was commonly or privately owned. From 1952 until 1956 the management of agricultural land was gradually pooled into larger collective units, ranging from Mutual Aid Teams and Lower Agricultural Production Cooperatives. The end to private land ownership was heralded in 1956, with the establishment of the Higher Agricultural Production Cooperatives. From 1958 onwards until the Four Fixes movement in 1962, agricultural land was owned by the People's Commune. 
Table 2 Authority and legal basis for titling per institution

\begin{tabular}{|c|c|c|c|c|c|c|}
\hline Type of property right & MLR & MoA & $S B F$ & MOHURD & MOCA & work-unit/collective \\
\hline \multicolumn{7}{|l|}{ Ownership of land } \\
\hline $\begin{array}{l}\text { ownership of collectively } \\
\text { owned rural land }\end{array}$ & $\mathrm{X}^{*}$ & & & & & \\
\hline $\begin{array}{l}\text { ownership of state-owned } \\
\text { rural and urban land }\end{array}$ & \multicolumn{6}{|c|}{ need not be registered by law** } \\
\hline \multicolumn{7}{|c|}{$\begin{array}{l}\text { Use right of land } \\
\text { 1) Use right to collectively owned land }\end{array}$} \\
\hline $\begin{array}{l}\text { use rights of collectively } \\
\text { owned agricultural land (lease } \\
\text { rights, i.e. Household Contract } \\
\text { System) }\end{array}$ & & $\mathrm{X}^{* * *}$ & & & & \\
\hline $\begin{array}{l}\text { use rights of collectively } \\
\text { owned grassland, forest and } \\
\text { wasteland }\end{array}$ & & $?$ & $?$ & & & \\
\hline $\begin{array}{l}\text { use rights of collectively } \\
\text { owned rural construction land } \\
\text { (housing) }\end{array}$ & $\mathrm{X}^{* * *}$ & & & & & \\
\hline \multicolumn{7}{|l|}{ 2) Use right to state-owned land } \\
\hline $\begin{array}{l}\text { use rights of urban land } \\
\text { (exception: land used by } \\
\text { national units/ministries } \\
\text { separately titled) }\end{array}$ & $\mathrm{X} * * *$ & & & & & \\
\hline $\begin{array}{llr}\text { use rights of rural } \\
\text { infrastructural } & & \text { land; } \\
\text { expropriated for } & \text { roads, } \\
\text { railways, bridges, etc. } & \\
\end{array}$ & $\mathrm{X}^{*}$ & & & & & \\
\hline $\begin{array}{l}\text { use rights of state-owned } \\
\text { grassland (includes use for } \\
\text { mining, military purposes, } \\
\text { etc.) }\end{array}$ & $\mathrm{X}+$ & $\mathrm{X}+$ & & & & \\
\hline $\begin{array}{l}\text { use rights of state-owned } \\
\text { forest (includes use for } \\
\text { mining, military purposes, } \\
\text { etc.) }\end{array}$ & $\mathrm{X}++$ & & $\mathrm{X}++$ & & & \\
\hline $\begin{array}{l}\text { use rights of state-owned } \\
\text { wasteland (includes mining, } \\
\text { military purposes. Rights to } \\
\text { riverbanks and riparian rights } \\
\text { not legally determined) }\end{array}$ & & $?$ & $?$ & & & \\
\hline Ownership of real estate & & & & & & \\
\hline
\end{tabular}




\begin{tabular}{|c|c|c|c|c|c|}
\hline $\begin{array}{l}\text { ownership rights of rural real } \\
\text { estate }\end{array}$ & $X^{*}$ & & & & \\
\hline $\begin{array}{l}\text { ownership rights of urban real } \\
\text { estate }\end{array}$ & & & $\mathrm{X}+++$ & & \\
\hline \multicolumn{6}{|l|}{ Use right of real estate } \\
\hline use rights of rural housing & & & & & $?$ \\
\hline use rights of urban real estate & ? & & & & ? \\
\hline \multicolumn{6}{|l|}{ Others rights } \\
\hline $\begin{array}{l}\text { Determination of } \\
\text { provincial-level boundaries }\end{array}$ & & & & $\mathrm{X}$ & \\
\hline $\begin{array}{l}\text { Ownership and use of fisheries } \\
\text { and beaches }\end{array}$ & & $\mathrm{X}^{\wedge}$ & & & \\
\hline $\begin{array}{l}\text { Ownership and use of } \\
\text { oceans/seas within national } \\
\text { territories }\end{array}$ & $X^{\wedge \wedge}$ & & & & \\
\hline
\end{tabular}

* 1998 Land Administration Law, Article 11, 12 and 13

** Not listed in law, see (Hu, 1998: p. 12)

*** 2002 Rural Land Contracting Law, Article 23

+ Grassland Law, Article 11

++ Forest Law, Article 3

+++ Urban Real Estate Administration Law, Chapter 5

$\wedge$ Fishery Law, Article 11

$\wedge \wedge$ Oceanic Use and Administration Law, Article 6 and 9 (formerly registered by State Oceanic Administration, since 2013 absorbed by Ministry of Land and Resources

Source: Drawn by author. Note that the symbol " $X$ " denotes a historically grown situation, not legally stipulated. Only the Forest Law mentions a specific institution for titling: the State Forestry Bureau (Article 3) 